Chinese Teachers' Views of Educational Exclusion of Children with Disabilities in Relation to Equality

Xiao Qu

University College London Institute of Education

Qu.xiao@hotmail.com

Published version: International Journal of Inclusive Education 


\section{Chinese Teachers' Views of Educational Exclusion of Children with Disabilities in Relation to Equality}

This paper examines one key theme of 'education and equality' arising from a qualitative study that explores what special and inclusive education may mean for Chinese primary schools. The focus is on unpacking teachers' interpretations, values, and deeper assumptions of the 'equality' concept. Drawing from 37 interviews with mainstream primary school teachers in a Chinese city, this paper illustrates that teachers may perceive the concept of 'educational equality' in terms of equal treatment and preferring utilitarian principles than equality. The analyses show how teachers' understanding surrounding 'education and equality' informs their views and attitudes of the inclusion and exclusion of children with disabilities. This paper intends to draw attention to and highlight the importance of the need for Chinese teachers to think more deeply about educational equality beyond equal treatment. Responding to utilitarian perspectives in special and inclusive education, the paper reminds the importance of recognising that inclusion in its broad sense has the benefits of improving education and society for all, not just for the few in minority. The conclusion suggests areas for further investigations.

Keywords: inclusive education, equal treatment, utilitarianism, educational equality, growth of segregated provisions

\section{Introduction}

In China, inclusion has been recognised as integral to national education policies since 1994 under the name of sui ban jiu du 'learning in regular classrooms' [LRC] (MoE, 1994). It has recently been reaffirmed as a priority in educational development (MoE, 2017a; State Council, 2019). Yet despite the policy discourse, the number of children with disabilities attending special schools in China has continued to rise with more special schools being built every year. There were 1,520 special schools with 371,625 students enrolled in 1999; and in 2016 the scale of segregated education has grown to 2,080 special schools with 491,740 
students enrolled (NBS, 2000, 2017). The increase was accompanied by a decline of children with disabilities in mainstream primary schools. In 2001, 69.86 per cent of children with disabilities who had access to formal education attended mainstream provisions, which was so far the highest point, and the number dropped to 54.6 per cent in 2016 (MoE, 2017b). Considering the inconsistency between China's global engagement with the inclusion agenda (UNESCO, 1990, 1994, 2015a) and the actual growing scale of segregated education domestically, it is rather a confusing message concerning the direction in which the country's inclusive education is heading.

To translate the inclusion policies into effective practices, difficulties arise from the wider socio-cultural contexts. China is a Confucian heritage culture with a claimed socialist political system. Confucianism supports a strictly hierarchical social order, where education has been used to cultivate elites for governance. This is clearly reflected in the Confucian saying: xue er you ze shi, officialdom is the natural outlet for good scholars (Analects, 19.13). Education for children with disabilities, which is not usually associated with producing elites, can be considered less important and often ignored (Deng \& Poon-McBrayer, 2012). The cultural emphasis on social hierarchy also means that people with disabilities are often regarded and treated to be in a weak, subordinate, and obedient social position in need of care, charity, and mercy (Xiong \& Deng, 2011). Without seeing children with disabilities as in equal social relationships with others, education can hardly become truly inclusive.

Equality is among the 'socialist core values' proposed by President Xi today in the Chinese society (CPC Central Committee, 2013; Xi, 2017). Xi (2017) stressed that the primary social conflict in China is “between people's growing needs for a better life and the unbalanced and insufficient development". This points to a heightened awareness for more equal shares of progress across regions and social groups. The latest national education 
development plan also specified that "education equity is one of the most pressing and sensitive problem in China's education system” (State Council, 2017, Article 4.5).

However, despite such official narratives of equality, there seems to be relatively low awareness among the general public (Zhang, 2016). A survey study conducted by Wu and Gu (2012) with 1,063 respondents across China finds that 85.7 per cent think that inequality will persist, and they accept it as part of society, and 60.2 per cent positively see inequality as necessary for social development. This result is not surprising under the long-standing trickle-down economic policy of "to let some parts of the society get rich first; they then have the responsibility to help and lead the rest to get rich as well; gradually common prosperity will be achieved" (Deng, 1993; Xi, 2014b).

In such a context, this paper examines in-depth one key theme of 'education and equality' arising from a qualitative study that aims to offer deeper understanding of what special and inclusive education may mean for Chinese primary schools. While the main study produces multiple findings, this paper only focuses on one theme of 'equality' as part of the exploration of Chinese primary school teachers' internal subjective agency regarding educational inclusion and exclusion. Other important themes form separate papers (e.g., Qu, 2019). As the front-line practitioners of education, teachers may practise inclusion or exclusion in part informed by their values and understanding of 'education and equality'. Individuals with personal identities and concerns "know what they care about most and what they seek to realise in society" (Archer, 2003, p. 130). Considering that educational equality is a main driver for inclusion, it is of importance to understand in what ways Chinese teachers actually care about 'educational equality'. Unpacking teachers' interpretations and deeper assumptions of the concept may help to explain what they seek to realise in their daily teaching regarding children with disabilities. This perspective may add to insights into how 
inclusion debates and practices may be moved forward in $21^{\text {st }}$ century China. It may also offer implications for advancing inclusive efforts elsewhere.

\section{Method}

This is a qualitative study conducted in 2016 using semi-structured interviews to explore what special and inclusive education may mean for Chinese primary schools. The main aim is to offer deeper understanding of teachers' beliefs concerning the educational inclusion and exclusion of children with disabilities. The analyses are exploratory focusing on meaningmaking without offering definitive conclusions. As part of the study, this paper examines indepth one key theme of 'education and equality' arising from the findings. The focus is on unpacking teachers' interpretations, values, and deeper assumptions of the 'equality' concept.

37 teachers from four mainstream schools in a Chinese city were interviewed at their schools. Participants include two headteachers, 14 head class teachers from both lower grades and higher grades, nine academic subject teachers, eight non-academic subject teachers, and four school administrative staff, with mixed gender, years of experience, and qualifications. ${ }^{1}$ 32 participants were female, as school staff were predominantly female.

Key statements made by the interviewees were translated into English and quoted as illustrative texts to assist the report of findings and analysis. Participant details using pseudonyms are given for those who are quoted in this paper after the illustrative quotes in brackets. The accuracy of my translation was verified by back translating all the quotes to

1 In a Chinese school, the 'head class teacher' is equivalent to the form tutor of a British school. This teacher however will play a leading role in the life and welfare of all class members for the duration of their time in school, and the role will usually occupy the bulk of their weekly time as a teacher. These form the basis of the pastoral system within the school. 
make sure the meaning did not change. This study was given ethical approval by the Institute of Education, University College London, where the research is affiliated.

The interviews were arranged by headteachers, school administrators, or myself directly liaising with the teachers. They last about 40-60 minutes each and were recorded with consent for later transcription. Main interview questions involved in the discussion of this paper concerned teachers' understanding of and attitudes towards the educational inclusion and exclusion of children with disabilities. For example: 'how do you understand the concept of inclusion?', 'do you think special schools are to do with educational inequality in any way? How and why?', and 'what do you think are the pros and cons of special schools and inclusive mainstream schools?'.

After transcribing all the interview recordings which were in Chinese, I read through the transcripts for multiple times and used thematic coding to highlight common and recurring themes that emerged from the data (Braun \& Clarke, 2006). In this process, the texts were broken down into chunks - words, sentences, paragraphs - according to themes so as to be examined for meaning. Two sub-themes emerged under the main theme of 'education and equality': seeing equality as equal treatment, and valuing utilitarian principles over equality. These form the main analyses and discussions that follow.

\section{Equality as Equal Treatment}

Equality is "normatively important" in education provisions because education is in part "a positional good" (Reich, 2013, p. 58). 'Positional good' refers to "the way the value of a certain good to a person depends on other people's not possessing that good, or not possessing as much of it" (ibid.). For children with disabilities who are already disadvantaged through no faults of their own, it is important that they are not doubly disadvantaged by 
educational inequality.

A plethora of literature has explored how educational equality can be interpreted, such as in terms of equality of access, treatment, outcome, opportunity, and adequacy (Coleman, 1968; Ladd \& Loeb, 2013; Le Grand, 2018). However, among the teachers from the four mainstream schools, equality rather appeared to be mainly understood as equal treatment. For example:

\footnotetext{
"We teach all children equally the same here. Like the boy [with emotional behavioural difficulties], ... he won't be discriminated in this school, and he won't get special treatments either. All students are taught the same way if they come here." (Guoming, Grade Five Maths teacher)

"Inclusion means that all children receive the same education here [in the mainstream school]." (Yunfeng, Grade Four Chinese teacher and head class teacher)
}

Following the understanding of equality as equal treatment, segregated provisions for children with disabilities were not commonly associated with inequality by participants. The logic is that 'equality' here means that teachers would provide the same support for all students in mainstream schools; children with disabilities then do not receive the additional support they may need to succeed; their 'failure' is contributed to their own ability level; and special schools are merely to provide the 'suitable' provisions for them, irrelevant to concerns of 'equality'. For example:

\footnotetext{
"Special schools have nothing to do with segregation or inequality. It's just a more suitable place for these children to develop. Every child has his/her most suitable place. If you think special schools are segregating, what about arts schools and sports schools? Are they also forms of segregation and inequality? I think it's about different children's directions of development in life, which ask for different educational environments. It's not about segregation or inequality." (Tinghui, Grade Five Maths teacher, deputy director of educational administration)
} 
Here the underlying assumption is that every child has a fixed ability which requires a certain type of 'most suitable' provision. It seemingly contradicts the notion of equal treatment as equality, but teachers did not appear to see this as a need to refine their concepts of 'equality' such as equal opportunities or outcome. Rather, they tended to dismiss the matter altogether as irrelevant.

This is fundamentally inseparable from what the teachers value and care about most (Archer, 2003). The functionalist value of certain children belonging to certain places seemed to overshadow concerns for educational inequality. In short, teachers may care more about functionalism than equality. Such functionalist views in education were common among participants. For example, Liangshu (Chinese subject teacher, Grade Six) said that it would be irresponsible to place a child with disabilities in a mainstream school because he/she does not fit into the mainstream environment; Quan (Head class teacher, Grade Two Maths teacher, deputy director of educational administration) said that categories of disabilities should be clearly distinguished and only the 'suitable' ones should attend mainstream schools; and Xiuqin (Grade Five Maths teacher, director of moral education) believed that if the children themselves cannot keep up with others in the mainstream environment, they should go to special schools. Clearly, with this functionalist mentality, what teachers stressed was that certain children do not fit into or benefit from the mainstream setting because of their own faults. This outlook ignores the institutional barriers to inclusion and the social responsibilities of how schools and teachers can adapt to meet diverse learner needs.

This functionalist view of special and inclusive education was inseparable from the medical model of disability, which finds faults within the individuals by their deficits and sees them as tragic victims with illness to be cured (Barton, 1993; Tomlinson, 1982). Under the medical model, children with disabilities can be perceived as necessarily requiring specialist expertise and hence a distinctly different group from other typically developing 
children. This again can make the concept of equality difficult to grasp if 'equality' only refers to equal treatments. For example, one teacher specifically drew parallels between hospitals and specials school, arguing that children attending special schools is as natural as patients going to hospitals:

\footnotetext{
"It's not about inequality. ... If you are sick, you go to the hospital. You can't say patients going to the hospital is a form of discrimination or exclusion. The purpose of setting up hospitals is to help people with illnesses. The same goes for special schools." (Xinyu, Grade One English teacher, on-site part-time psychologist)
}

Equating hospitals and special schools as essentially the same reflects a medical deficit model of disability. It not only regards children with disabilities primarily as patients, but it also highlights the division between the 'normal' and the 'abnormal', dismissing the question of equality as irrelevant. To further illustrate:

\footnotetext{
"By definition, this group of people [with disabilities] is special. If you forcefully put them in a normal environment, they can never integrate and become part of the larger crowd." (Dinglu, Grade Five Chinese teacher)

"How can they [children with disabilities] be the same as the normal children? For sure not. ... their education needs different requirements and contents, so you can't think about it in terms of equality or inequality. ... They are also receiving an equal education in special schools." (Wengfan, Grade Five Maths teacher)
}

The deep assumption here is that children with disabilities themselves are not equal to other children, so in these teachers' views, the education they 'deserve' should also be 'equally different' such as in special schools. In this sense, special schools are seen as moral and just because they respect children's equal access to education based on needs. This language - needs can be so special that they are necessarily outside mainstream schools' capacity - can be easily used to justify exclusion. For example: 
"There is really not much the school can do...It's impossible for us to correct the child because we don't have the expertise in that area...Right now there isn't any mainstream school that is able to teach him [an autistic boy]. (Jingjing, Director of education administration)

Equality as equal treatment here further helps to legitimise such excluding thinking: schools are only supposed to offer the same education and teaching to everyone. However, equal treatment as equality has been much challenged in literature. Instead, equality has been defended to be about giving more benefits to the worst off. Nagel ([1970]2012) maintains that as a matter of the principle of equality, it is more urgent and important to help and improve the situations of the people in worse positions even if they are harder to help. Raphael (1980) similarly notes that: "if the man [sic] with greater needs is given more than the man [sic] with lesser needs, the intended result is that each of them should have (or at least approach) the same level of satisfaction; the inequality of nature is corrected" (p. 49). Thus, the aim of equality sometimes needs to be achieved through an 'inequality of treatment', so that "everybody should, as far as possible, have an equally worthwhile life" (Norman, 1987, p. 80).

Rawls (1971) also posited that a just society should give priority to the worse off. His thought experiment of the 'original position' outlines that "no one knows his place in society, his class position or social status; nor does he know his fortune in the distribution of natural assets and abilities, his intelligence and strength, and the like.... The principles of justice are chosen behind a veil of ignorance" (ibid., p. 118). This describes a fair, just, and equal society that each individual would want if no one knows in advance who they would be. Following this, considering that 15 per cent of the world population has some form of disability (WHO, 2011) - and many more at some part of their life -, one may not want to live in a society where there is a 15 per cent chance that he/she would be segregated, discriminated, or stigmatised because of disability. Individuals would then logically prefer 
social distributions where people with disabilities are treated fairly and given more resources to ensure their wellbeing.

However, in reality, there are rarely such impartial judgements as in the original position, and distribution preferences in front of and behind the Veil of Ignorance often differ (Schildberg-Hörisch, 2010). Individuals may value their self-interest more than social equality and fairness for others, especially if they already know that they are the ones who are better off. For example, Bjerk's (2016) laboratory experiment with 86 participants exploring their motivations for monetary redistribution shows that, when the participants knew their earning outcomes, most acted out of their own financial interest: 70 per cent of those with earnings above the means proposed no redistribution, while 60 percent of those with earnings below the means wanted complete redistribution; similar motivations were also found when participants did not know their earning outcomes: the study suggests that rather than preferring a more equal distribution on the ground of fairness and justice, participants were merely attempting to ensure themselves against the prospect of the low earning outcome. Similarly, Frignani and Ponti's (2012) study on distribution preference with 192 participants proposes that decisions under the Veil of Ignorance can be simply based on risk aversion rather than principles of social equality and justice.

Thus, going back to teachers' belief of equal treatment, similar arguments can be made. As individuals can be driven by self-interest and risk aversion, they may not prioritise values of equality, fairness, or justice for others unless they are in worse-off positions themselves. It can be in teachers' self-interest not to provide additional support for children with disabilities who are often exempted from exams, and to save the time and energy to focus on producing high achieving students. In this sense, equal treatment may just be a seemingly plausible and easy excuse to avoid talking about the complexity of inequality in education. It points to that fundamentally, equality was not thoroughly thought about or 
valued as a top concern by teachers. Just as Quan said regarding segregated education: “it's not a matter of inequality at all”.

Education, "beyond all other devices of human origin, is the great equaliser of the conditions of men [sic] - the balance-wheel of the social machinery" (Mann, 1848). Yet when equality is narrowly viewed as equal treatment and dismissed as irrelevant in education, it allows a segregated system that exacerbates and perpetuates inequality and prejudice. What is urgently needed is thus to explore ways to promote greater awareness of equality as necessary and integral to education, and also as equal opportunity or outcome beyond narrowly equal treatment. Yet this alone is not enough. 'Equality' altogether may become a peripheral concern in utilitarian ethics. The next section considers this in detail.

\section{Equality versus Utilitarianism}

Utilitarianism maximises utility, usually in terms of happiness or wellbeing. Propagated by Bentham ([1789]1907) and Mills ([1863]1998), it posits that the moral action is one that produces the greatest sum of happiness for the greatest number of people. Today in popular culture, it is often discussed in relation to the thought experiment of the Trolley Problem and similar related dilemmas. ${ }^{2}$ A utilitarian view sees it as the moral and right decision to steer the trolley or switch the track to kill one worker in order to save five, as the utility it generates by saving five workers is greater than saving one.

2 The Trolley Problem can be described as: "an out-of-control trolley is barreling toward five track workers who are trapped on the track ahead of it. If the driver does nothing, the five will be run over and killed. The driver cannot stop the trolley, but he can turn it onto a spur of track to the right, on which there is another trapped track worker who would be run over and killed were he to do so" (Graham, 2017, pp. 168-9). 
However, not only happiness as a personal feeling is not objectively measurable (Briggs, 2014), utilitarian principles can also raise questions for social equality and justice (Hare, 1981; Rosen, 2003). In the example of the Trolley Problem and its variations, it is morally justifiable to harm the minority of individuals in order to maximise the greatest happiness of the majority, even if it means to involve innocent bystanders. Critiquing such a stance, Nozick (1974) argues that:

\footnotetext{
"There is no social entity with a good that undergoes some sacrifice for its own good. There are only individual people, different individual people, with their own individual lives. Using one of these people for the benefit of others, uses him and benefits the others. Nothing more. What happens is that something is done to him for the sake of others. Talk of an overall social good covers this up". (pp. 32-3)
}

Indeed, the rhetoric of the greater good may sound compelling, yet what the greater good is exactly and whose good it represents needs to be questioned. As Rawls (1972) points out, "the plurality of distinct persons with separate systems of ends is an essential feature of human societies" (p. 29). Since individual happiness is diverse, and some may even contradict one another, it then follows that the greater good that is claimed to be the aggregation of individual happiness is rather a delusion. It may as well be the interest of the powerful. It may be the tyrannical power of the majority or the coercive power of the elite minority. In either case, the power is exerted when "the desires, needs, satisfactions, and dissatisfactions of distinct persons [are treated] as if they were the desires, etc., of a mass person" (Nagel, [1970]2012, p. 134). Clearly, the greatest sum of benefits that the abstract 'mass person' has does not distinguish among concrete individuals. In Nozick's (1974) words, such doing "does not sufficiently respect and take account of the fact that he is a separate person, that his is the only life he has" (p. 33). This points to concerns for social justice and equality. In this regard, as Parfit (1997) suggests, what matters is not just the greatest happiness, but also how well-off individuals would be; this may require that "we 
should sometimes choose a smaller sum of benefits, for the sake of a better distribution" ( $p$. 203). In short, one cannot make the utilitarian choice comfortably and uncritically only considering the consequences of one's actions. Perhaps a deontological perspective that upholds rules, principles, rights, duties, and obligations also needs to be considered and even given more weight in some cases.

In the context of education, utilitarianism can present challenges for the inclusion of children with disability. The educational exclusion of these children can be seen as particularly legitimate if they are considered as having a potentially negative effect on the majority of other children in mainstream schools (Allan, 2008; Slee, 2011). In this regard, Slee (2001) questions how the institutional exclusion of the 'abnormal' can ever be justifiable based on sacrificing these children's education for the sake of the majority.

However, teachers were found to make utilitarian choices regarding children with disabilities easily. An assumption was that an inclusive mainstream classroom would necessarily entail the irreconcilable conflict between the majority of the 'normal' children and the minority of children with disabilities in general. With a utilitarian mentality, when facing such a conflict of interest, if any, it is natural, right, and moral that the interest of the majority should be protected first even if it means to sacrifice the minority. To illustrate, Quan said that:

"I don't have enough energy to take care of both the majority of the normal children and a few special ones. These are two conflicting sides themselves anyway. It's hard to reach a balance. Certain people's interests have to be sacrificed. Either it's the normal people's interests or the special groups' interests. If the special groups can't get the support they need in our normal classes, it's better for them to go to special schools." (Quan, Grade Five Maths teacher, director of moral education)

The educational exclusion of children with disabilities can be seen as particularly legitimate if they are considered as having a potentially negative effect on the majority of 
other children in mainstream schools (Allan, 2008; Slee, 2011). Admittedly, at cases disruptive and challenging behaviours may affect others in a mainstream class. In a classroom of 45 students, which was the standard class size across the research sites, it can also be demanding for one teacher to manage difficult behaviours. However, these extreme cases cannot represent the diverse needs of children who experience educational exclusion. A substantial body of research (Andaya et al., 2015; Gandhi, 2007; Kalambouka et al., 2007; Dessemontet \& Bless, 2013) show that children with disabilities in mainstream schools do not have a negative impact on the academic achievement of the typically developing children. On the contrary, studies (Farrell et al., 2007; McLeskey, Waldron \& Redd, 2014) find that typically developing children can benefit from inclusion academically, as effective inclusive schools actively encourage and support teachers to continuously improve their practices to meet the needs of all their students. This reflects the spirit of inclusion, that is, "a dynamic approach of responding positively to pupil diversity and of seeing individual differences not as problems, but as opportunities for enriching learning" (UNESCO, 2005, p. 12). Thus, it is overly generalised to juxtapose children with disabilities and their typically developing peers as two incompatible, conflicting sides. The utilitarian morality here may be used as an excuse to avoid thinking more deeply about the complex question of inclusion.

The utilitarian thinking is also behind teachers' unwillingness to make special arrangements for students with disabilities. For example:

\footnotetext{
"You can't ask the normal schools to spend too many efforts in promoting inclusion, because after all the abnormal children are a very small minority. It's impossible for all the teachers to just leave the majority of their students aside and to study about special education and inclusion. But for special schools, teaching these children are their specialities, so these provisions should be greatly promoted." (Liangshu, Grade Six Chinese teacher)
} 
Liangshu appeared to assume that children with disabilities and their mainstream peers were completely two different groups requiring distinct instructions. Yet often, what benefits children with disabilities also often benefits other children in general. As many (Allan, 1999; Ainscow, 2007; Armstrong \& Moore, 2004; Florian, Black-Hawkins \& Rouse, 2016; Slee, 2001) have argued, by recognising and valuing the diversity of all learners and their equal right to quality education, inclusive education promotes the presence, participation, and achievement of all pupils in mainstream classrooms. Inclusive teachers do not just 'leave' the majority of their students. They seek to improve education for all children. But utilitarian principles offer an easy and quick conclusion that it is of course the minority of 'special' children that should be sacrificed for the sake of the majority. In Cuiling's words:

\footnotetext{
"It's irresponsible that one child like these makes the entire class disorderly. ... If that child goes to a special school, maybe his/her conditions may become even worse, but this is just the way the society is. You have to be responsible for the majority of the people." (Cuiling, Great Two \& Five Art teacher)
}

Clearly, the case for inclusion and educational equality is undermined by the realities that many believed that educational exclusion can be justified with the utilitarian principles, that children with disabilities are threats to others, and that school education can be a single choice question between the majority and the minority students. In this light, as Safford and Safford (1996) highlight:

\footnotetext{
"the implied cultural-utilitarian formula does not explain, assuming the importance primitive peoples must have ascribed to strength, stamina and sensory acuity, archaeological and anthropological evidences of protection and inclusion of members with physical and sensory impairments." (p. 3)
}

Armstrong (2002) similarly reminds that the need for individuals to be socially useful or productive cannot be the only determining values and concerns. What cannot be ignored is a deontological ethics model, that actions are judged as right or wrong based on rules and 
principles, not consequences. It is doubtful that everyone would want to live in a utilitarian society that treats individuals mostly as productive units and comfortably sacrifices the minority for the sake of the majority. Challenging the utilitarian orthodox and imagining alternatives may give hope for creating a more humanistic society that values dignity, compassion, equality and rights.

\section{Conclusion}

This paper has shown how equality may be understood among Chinese teachers in terms of equal treatment. Children with disabilities can be understood as an inherently different group based on the medical model of disability and functionalist thinking. These perspectives can be so strongly valued that 'equality' is dismissed as irrelevant when thinking about segregated education for different groups. Special schools instead may be believed to be moral and just because they are seen as respecting children's equal access to education based on ability. Yet this position can be challenged by the contention surrounding 'ability grouping' in literature. Studies have frequently found a negative impact of ability grouping on all groups, and particularly on children in low attainment groups in terms of learner identities, self-confidence, educational experiences, and learning outcomes (Francis et al., 2016; Francis \& Wong, 2013; Kutnick et al., 2005; Slavin, 1990).

In addition, utilitarian principles can be valued more than equality, especially when resources are scarce and choices have to be made, such as in China, an economically developing country with the world's largest population. Educational segregation was justified on the utilitarian ground of protecting the interest of the majority of typically developing students against the potential risk of being negatively influenced by children with disabilities. Utilitarianism as a barrier to inclusion can become particularly prominent when the concept 
of inclusion was narrowly understood as only benefiting the minority children with disabilities. This points to the importance of recognising that inclusion in its broad sense has the benefits of improving education and society for all, not just for the few in minority (Alderson, 2018; Armstrong, 2008; Florian \& Linklater, 2010; Knight, 2017).

Today a global consensus is increasingly that education is not just about producing economically productive citizens or acquiring knowledge and skills, it is also about "values of respect for life and human dignity required for social harmony in a diverse world" (UNESCO, 2015, 37). White $(2016,125)$ argues that education's role is to equip people to lead a meaningful life by "helping them to acquire the framework, or structure, of goals, relationships, norms, affective reactions and so on". A segregated education system undermines this role, affecting both children with disabilities and others: learning goals are narrowly driven by gaining merits; relationships are prejudiced and biased; norms are used to coerce and divide; and compassion, care, and respect for one another become peripheral to competing to win. In contrast, inclusive education, as "an ethical project of responsibility to ourselves and others" (Allan, 1999, p. 126), aims to create a more equal and just society, where each child is recognised as having strengths and weaknesses, and they learn in mixed groups how to live together (Alderson, 2018; Francis and Wong, 2013). It encourages an inclusive model of society in school that teaches children about togetherness, respect for differences, equality, kindness, compassion, and helping the least fortunate benefits all. Yet when teachers value equal treatment more than equal opportunities, and utilitarianism more than equality and justice, what they are driven to realise in education is also accordingly a narrowly functionalist and utilitarian version of society, such as the growing segregated provisions for children with disabilities.

Thus, the inclusion debate cannot underestimate or ignore teachers' internal subjective agency regarding education and equality. The process of weighing pros against 
cons determines one's preferences in decision-making (Archer, 2003). Teachers who do not believe in inclusion because they do not value equal opportunities much are unlikely to develop or sustain inclusive views or practices even if the desirable conditions are all in place. In the Chinese context, as illustrated in this paper, the medical model of disability, functionalism, and utilitarianism may present main barriers within the mind for teachers to recognise the significance of 'equality' and to develop deeper and more rounded understanding beyond equal treatment. Future studies are encouraged to examine more deeply how these specific barriers are contextualised within the Chinese socio-culture and how they may be addressed.

\section{References}

Ainscow, M. (2007). Taking an inclusive turn. Journal of Research in Special Educational Needs, 7(1), 3-7.

Alderson, P. (2018). How the rights of all school students and teachers are affected by special educational needs or disability (SEND) services: Teaching, psychology, policy. London Review of Education, 16(2), 175-190.

Allan, J. (1999). Actively seeking inclusion: Pupils with special needs in mainstream schools: Insiders, outsiders and deciders. London: Routledge.

Allan J. (2008). Rethinking inclusive education: The philosophers of difference in practice. Springer: Netherlands.

Analects E-publication: Chinese Text Project. Available from: https://ctext.org

Andaya, O. J., Aquino, L. N., Balot, M. A., Ganal, N. N., Leaño, A. J., Maguigad, R. Z. T., Miguel, C. G. \& Remigio, D. B. (2015). Assessing of the implementation of inclusive education among children and youth with special needs. The Normal Lights, 9(2), $72-$ 89.

Archer, M. S. (2003). Structure, agency and the internal conversation. Cambridge: Cambridge University Press.

Armstrong, F. (2002). The historical development of special education: humanitarian rationality or 'wild profusion of entangled events'? History of Education, 31(5), 437456.

Armstrong, F. (2008). Inclusive education. In G. Richards and F. Armstrong (Eds.), Key issues for teaching assistants: Working in diverse and inclusive classrooms, pp. 7-18. Oxon: Routledge.

Armstrong, F. \& Moore, M. (2004). Action research: Developing inclusive practice and transforming cultures. In Armstrong, F. and Moore, M. (Eds.), Action research for inclusive education. Changing places, changing practice, changing minds, pp. 1-16. London: Routledge. 
Barton, L. (1993). The struggle for citizenship: The case of disabled people. Disability, Handicap and Society, 8(3), 235-48.

Bentham, J. ([1789]1907). An introduction to the principles of morals and legislation. Oxford: Clarendon Press.

Bjerk, D. (2016). In front of and behind the veil of ignorance: An analysis of motivations for redistribution. Social Choice and Welfare, 47, 791-824.

Braun, V. \& Clarke, V. (2006). Using thematic analysis in psychology. Qualitative Research in Psychology, 3(2), 77-101.

Briggs, R. (2014). Normative theories of rational choice: Expected utility. The Stanford Encyclopaedia of Philosophy. Available at: https://plato.stanford.edu/entries/rationalitynormative-utility/

Coleman, J. (1968) The concept of equality of educational opportunity. Harvard Educational Review, 38 (1), 7-22.

CPC (Chinese Communist Party) Central Committee (2013). [In Chinese]. Opinions on cultivating and implementing socialist core values. Available from: http://xsc.dhu.edu.cn/inquiry/upload/richArea/file/20161110/1478749339965159.pdf

Deng, X. P. (1993). [In Chinese]. Selected works of Deng Xiaoping, vol. 3. Beijing: People's Publishing House.

Deng, M. \& Poon-McBrayer, K. (2012). Reforms and challenges in the era of inclusive education: The case of China. British Journal of Special Education, 39 (3), 117-122.

Dessemontet, R. S. \& Bless, G. (2013). The impact of including children with intellectual disability in general education classrooms on the academic achievement of their low-, average-, and high-achieving peers. Journal of Intellectual \& Developmental Disability, 38, 23-30.

Farrell, P., Dyson, A., Polat, F., Hutcheson, G. \& Gallannaugh, F. (2007). Inclusion and achievement in mainstream schools. European Journal of Special Needs Education, 22, 131-145.

Florian, L., Black-Hawkins, K. \& Rouse, M. (2016). Achievement and inclusion in schools, 2nd ed. London, Routledge.

Florian, L. \& Linklater, H. (2010). Preparing teachers for inclusive education: Using inclusive pedagogy to enhance teaching and learning for all. Cambridge Journal of education, 40 (4), 369-386.

Francis, B., Archer, L., Hodgen, J., Pepper, D., Taylor, B. \& Travers, M. C. (2016). Exploring the relative lack of impact of research on 'ability grouping' in England: A discourse analytic account. Cambridge Journal of Education, 47(1), 1-17.

Francis, B., \& Wong, B. (2013). What is preventing social mobility? Literature review. Leicester: ASCL.

Frignani, N. \& Ponti, G. (2012). Risk versus social preferences under the veil of ignorance. Economics Letters, 116(2), 143-146.

Gandhi, A. G. (2007). Context matters: Exploring relations between inclusion and reading achievement of students with- out disabilities. International Journal of Disability, Development and Education, 54, 91-112.

Graham, P. A. (2017). Thomson's trolley problem. Journal of Ethics and Social Philosophy, 12 (2), 168-190.

Hare, R. M. (1981). Moral thinking. Oxford: Oxford University Press.

Kalambouka, A., Farrell, P., Dyson, A. \& Kaplan, I. (2007). The impact of placing pupils with special educational needs in mainstream schools on the achievement of their peers. Educational Research, 49, 365-382. 
Kutnick, P., Blatchford, P., Clark, H., MacIntyre, H. \& Baines, E. (2005). Teachers' understandings of the relationship between within-class (pupil) grouping and learning in secondary schools. Educational Research, 47(1), 1-24.

Knight, S. (2017). Ten steps to become a better teacher of pupils with SEND, TES, 17 November. Retrieved from: https://www.tes.com/news/ten-steps-become-better-teacherpupils-send

Ladd, H. \& Loeb, S. (2013). The challenges of measuring school quality - Implications for educational equity. In: D. Allen \& R. Reich (Eds). Education justice \& democracy, pp. 19-42. Chicago and London: The University of Chicago Press.

Le Grand, J. (2018). The strategy of equality: Redistribution and the social services. London: Routledge.

McLeskey, J., Waldron, N. L. \& Redd, L. (2014). A case study of a highly effective, inclusive elementary school. The Journal of Special Education, 48, 59-70.

Mills, J. S. ([1863]1998). Utilitarianism. Oxford: Oxford University Press.

Mann, H. (1848). Twelfth annual report to the Massachusetts State Board of Education. Massachusetts: Commonwealth of Massachusetts, Board of Education.

MoE [Ministry of Education] (1994). [In Chinese]. Trial procedures of admitting disabled children/teenagers to regular classrooms. Beijing: MoE.

MoE (2017a). [In Chinese]. Special education promotion plan 2017-2020. Beijing: MoE.

MoE (2017b). [In Chinese]. Overview of education in China ---- National education development in 2016. Beijing: MoE.

Nagel, T. ([1970]2012). The Possibility of Altruism. Princeton: Princeton University Press.

Norman, R. (1987). Free and equal. Oxford: Oxford University Press.

Nozick, R. (1974). Anarchy, State and Utopia. New York: Basic Books.

NBS [National Bureau of Statistics of China] (2000). [In Chinese]. China statistical yearbook of 2000. Beijing: NBS.

NBS (2017). [In Chinese]. China statistical yearbook of 2016. Beijing: NBS.

Parfit, D. (1997). Equality and priority. Ratio, 10(3), 202-221.

$\mathrm{Qu}, \mathrm{X}$. (2019). Rethinking Norms and Collectivism in China's Inclusive Education - Moving Teachers' Understanding beyond Integration. Journal of Research in Special Educational Needs (In Press).

Raphael, D. D. (1980). Justice and Liberty. London: Athlone Press.

Rawls, J. (1972). A theory of justice. Oxford: Clarendon Press.

Reich, R. (2013). Equality, adequacy, and K-12 education. In: D. Allen \& R. Reich (Eds.), Education justice \& democracy, pp. 43-61. Chicago and London: The University of Chicago Press.

Rosen, F. (2003). Classical utilitarianism from Hume to Mill. London \& New York: Routledge.

Safford, P. L. \& Safford, E. J. (1996). A history of childhood and disability. New York and London: Teachers College Press, Columbia University.

Schildberg-Horisch, H. (2010). Is the veil of ignorance only a concept about risk? An experiment. Journal of Public Economics, 94(11-12), 1062-1066.

Slavin, R. E. (1990). Achievement effects of ability grouping in secondary schools: A bestevidence synthesis. Review of Educational Research, 60(3), 471-499.

Slee, R. (2001). Driven to the margins: Disabled students, inclusive schooling, and the politics of possibility. Cambridge Journal of Education, 31(3), 385-397.

Slee, R. (2011). The irregular school. Exclusion, schooling and inclusive education. Milton Park: Routledge.

State Council (2017). [In Chinese]. Thirteenth five-year plan for national education development. Beijing: State Council. 
State Council. (2019). [In Chinese]. Chinese education modernisation 2035. Beijing: State Council.

Tomlinson, S. (1982). A sociology of special education. London: Routledge.

UNESCO [United Nations Educational, Scientific and Cultural Organization] (1990). World declaration on education for all. Paris: UNESCO.

UNESCO (1994). The Salamanca statement and framework for action on special needs education. Paris: UNESCO.

UNESCO (2015). Rethinking Education: Towards a Global Common Good? Paris: UNESCO.

White, J. (2016). Reply to Anders Schinkel on 'Education and ultimate meaning'. Oxford Review of Education, 42 (1), 123-128.

WHO (World Health Organisation) (2011). World health statistics 2011. Geneva: WHO.

Wu, J. \& Gu, Z. J. (2012). [In Chinese]. A survey report on the views regarding equality and privileges among the general public in China. Frontiers, 11, 76-85.

Xi, J. P. (2014b). The Governance of China. Beijing: Foreign Languages Press.

Xi, J. P. (2017). [In Chinese]. Xi Jinping's report at the 19th National Congress of the Chinese Community Party. 18 October, National Congress, Beijing. Available from: http://www.gov.cn/zhuanti/2017-10/27/content_5234876.htm

Xiong, X. Q. \& Deng, M. (2011). [In Chinese]. The tolerance features and modern development of inclusive education. Journal of Continue Education Research, 12, 8-11.

Zhang, Y. H. (2016c). [In Chinese]. Surveys on the human rights awareness among the Chinese general public. Beijing: China Renmin University Press. 


\section{A Critical Realist Model of Inclusive Education}

\section{Xiao Qu}

University College London Institute of Education

20 Bedford way, Bloomsbury, London WC1H 0AL

Qu.xiao@hotmail.com

Manuscript under review: British Education Research Journal 


\section{A Critical Realist Model of Inclusive Education}

The ways 'disability' is viewed can inform the design of education for children with disabilities. To date, despite the clear global inclusion agenda, gaps remain in the translation of the philosophical acceptance of inclusion principles into effective teaching practices. The support for segregated schools hinged on the medical model of disability with a positivist approach still challenges inclusive education that is driven by the social and rights-based models with an interpretivist stance. The debates that are for or against inclusion usually take these two polarised paradigms, which need to be openly addressed if disagreements are to be resolved. This paper suggests threedimensional critical realist models of disability and inclusive education in the hope of moving the inclusion debates forward. The paper contends that the stratified ontology may offer the necessary theoretical grounding to bridge the current paradigm division and make sense of the contradictions and inconsistencies in the special and inclusive education practices. The usefulness of a CR model of inclusive education is to paint a holistic picture beyond the usually isolated single focal points in education. Different fields of professionals need to work inclusively together towards different depths of children's best interests, such as physical, psychological, academic, social, and cultural.

Keywords: paradigm division, medical model, social model, stratified ontology

\section{Introduction}

It is a global consensus that inclusion, driven by concerns for children's rights and school effectiveness, is a key principle in education, especially relevant for vulnerable children such as those who are identified with special educational needs and/or disabilities [SEND] (Lindsay, 2007; UN 1989, 2006, 2015; UNESCO, 2015, 2017). In practice, however, there has always been disagreement regarding in what forms and to what extent can meaningful inclusion feasibly happen. For example, dilemmas of differences (Norwich, 2008) continues to raise difficult questions for decision-making regarding inclusive provisions. Complex problems persist such as Armstrong's (2018) list of 'wicked problems' in special and 
inclusive education in the four main categories of neoliberalism, curriculum, pedagogy, and attitudes. Different paradigms of approaching 'disability' (e.g., the medical and social models of disability) also lead to conflicting views as for how children's interests and rights can be best honoured, such as in the form of full inclusion, a continuum of provisions, or special schools.

Amid various and sometimes conflicting positions, one consensus is that no one (politicians, scholars, medical professionals, school managers, teachers or parents) is allegedly against rights, justice, equality, or quality of education. All claim to work towards the best interest of the child, medically, educationally, or socially, in segregated or inclusive provisions. Empirical studies so far also have yet to conclusively show convincing, overwhelming, and generalisable evidence that what provisions are best for children with what types of SEND (Lindsay, 2007; Loreman, 2014). After more than two decades of initiating the global inclusion agenda (UNESCO, 1994), today inclusive education continues to be challenged by exclusion. Special schools - primarily driven by the medical model have been and are still supported by scholars, teachers, and parents in good faith, while inclusion - underpinned by the social and rights-based models can be doubted as 'unrealistic', 'idealistic' or 'utopian' (Guan, 2017; Head, Kane \& Cogan, 2002; Kauffman, 1992, 2015). Subsequently, there has been an increasing number and percentage of children with SEND enrolled in segregated schools in parts of the world (DfE, 2017; NBS, 2000, 2017).

It is in such a context that this paper seeks to construct a conceptual framework that helps to make sense of the contradictions and inconsistencies in special and inclusive education and to unite rather than divide the current debates in the hope of moving the field forward. The theoretical approach taken is critical realism [CR]. The following sections first introduce the CR ontology of the stratified reality; then main SEND paradigms of the medical 
and social models are reviewed before illustrating how CR models of disability and inclusive education can be helpful.

\section{The CR Stratified Ontology}

The age-old opposition between the positivist and interpretivist ontology still informs different ways the world is perceived and knowledge created today. Gorski (2013, p. 660) identifies that "positivism is the dominant form of orthodoxy, and interpretivism is the dominant form of heterodoxy, and most social scientists position their methodological approaches implicitly or explicitly in relation to these two stances". A positivist view aims to generalise and discover causal relationships through empirical observation and quantitative measurement of key variables. While an interpretivist perspective stresses the in-depth qualitative understanding of the particularity and is "exploratory", "open-ended", "datadriven" and "inductive" (Taber, 2012, p. 129). In the field of educational research, Hammersley (2012) notes that up until the end of the 1960s, positivist work characterised by topics such as standardised tests, school experiments, observation, survey, and statistical analysis had been dominant, but more recently there has also been a growth of qualitative research.

However, these opposing research paradigms have been frequently criticised. Danermark and colleagues (2001) highlight that positivist assumptions mainly suit the study of natural science in a closed system, while interpretivist standpoints would reject the reality of social structures and ignore the objective aspects of the world. In the social sciences and especially for inclusive education, phenomena cannot be studied independently of social contexts as they are constantly shaped by various external elements in open systems (Alderson, 2013); nor can studies produce highly relevant analysis of powerful influences if the social structures in the real world are ignored. 
CR overcomes these problems by bringing the two traditions together. It responds to the problems of positivism and interpretivism. CR accepts the existence of an objective world independent of human perception and the possibility of knowing that independent reality (Bhaskar, 1998, 2008). It also acknowledges that the intrinsically meaningful social phenomena have to be qualitatively understood (ibid.).

Broadly, CR distinguishes between transitive and intransitive dimensions of knowledge. Bhaskar (2008, p. 21) argues that the transitive dimension is human thinking, remembering, perceiving, interpreting and the concepts, theories, and laws, which are "the raw materials of science - the artificial objects fashioned into items of knowledge by the science of the day". In contrast, the intransitive dimension involves "structures, mechanisms and real things, events, possibilities and processes of the world" (ibid., p. 22) that are independent of human perception. In the transitive dimension, CR acknowledges that the world is not experienced as value-neutral (Collier, 1999; Porpora, 2015; Sayer, 2017), and that there are variations of interpretations of the same event depending on different individual perspectives in different social contexts. Through this fallible knowledge - different observations and experiences, among which, some can be closer than reality than others -, the intransitive objective world can be understood. In this, CR highlights the pitfall of 'epistemic fallacy' - collapsing being into knowing, independent ontology into epistemology. The transitive, fallible knowledge needs to be separated from the intransitive, though changing, objective reality (Bhaskar, 1998, 2008).

Further, Bhaskar $(1998,2008)$ distinguishes three domains of reality as the Empirical, the Actual, and the Real. The surface level of the Empirical refers to humans' observations and experiences of events; the actual is the events that objectively occur independently of subjective perceptions, whether observed or not; and the deep level of the real includes 
whatever exists, which is only manifested through its causal effect and not directly perceivable. See Table 1 below:

Table 1. Stratified Ontology (Bhaskar, 2008)

\begin{tabular}{|c|c|c|c|}
\hline & Domain of Empirical & Domain of Actual & Domain of Real \\
\hline Experiences & $\times$ & $\times$ & $\times$ \\
\hline Events & & $\times$ & $\times$ \\
\hline Mechanisms & & & $\times$ \\
\hline
\end{tabular}

This stratified ontology distinguishes CR from other research philosophies adhering to a flat ontology such as positivism and interpretivism. Scientific knowledge is seen as a process of disclosing what lies underneath experienced events, and acknowledging that the observed phenomena do not exhaust what could happen or has happened (Sayer, 2000). Critical realists (Bhaskar, 1998, 2008; Gorski, 2013; Porpora, 2015; Sayer, 2000) commonly affirm that the central task for CR researchers is to uncover the structure and generative mechanisms in the real domain.

The stratified ontology is helpful to develop deep understanding in that it requires mindfully looking for causes behind what has been perceived at the surface level of events. In special and inclusive education, for example, first, all that can be empirically observed only constitutes the Empirical. This may include the identification and measurement of differences, individuals' learning and teaching experiences, policies and research, attainment results, and interpersonal interaction outcomes. Debates focusing on this level only would easily fall under the positivist - medical model paradigm that prioritises 'hard proofs' for what has and has not worked.

Second, the Actual involves all that has happened despite being observed or not. This may include everyday learning and teaching activities, school organisation and operation. 
The Actual is also considered by interpretivists, but they often reduce the Actual into the intricacy of individuals' meaning-making contextualised within the social world's open system.

Third, the Real explores why and how it exists. This level is about the conflicting and converging causal mechanisms that shape special and inclusive education, such as neoliberalism, utilitarianism, children's rights, and ideals for an equal and just society. This stratified ontology can guide critical analysis to identify deep causes of resistance against inclusion, inform policies to develop effective solutions, and bring about authentic change.

A CR approach to arrive at the Real is what Bhaskar (2009) called 'retroduction', a transcendental cognitive process to identify unobservable causal mechanisms based on their observable effects in the empirical world. It is a method of inference that uses the individuated elements of phenomena to achieve a transcendental understanding of what the world must be like in order for phenomena to exist and act as the way they do (ibid.; Danermark et al., 2002), such as 'what must be in place for inclusion to happen?' In Bhaskar's (2009, p. 11) words, retroductive arguments move "from a description of some phenomenon to a description of something which produces it or is a condition for it". This means that retroduction goes beyond the observed manifested effects of the phenomenon studied, and searches for essential relations that make the phenomenon happen (and not happen). Through this cognitive process of moving back and forth between the observed events and possible explanations, deeper knowledge of the complex reality can be gained.

With a clear framework of the CR stratified ontology, the next section first reviews the key debates within the medical-social model division before applying the framework to construct a CR model of disability. 


\section{A Tale of Two Models: Medical versus Social}

Historically, children with disabilities have often been seen as 'uneducable' and routinely denied access to formal education. In the 1900s, special education as a sub-system of formal education started to develop first in the West as a then-revolutionary idea to provide some form of public education for children with disabilities. Residential schools for blind and deaf children, and sub-normality hospitals for 'ineducable' children with learning difficulties were part of eugenic efforts to reinforce their life-long segregation from mainstream society (Quicke, Beasley \& Morrison, 1990). By the mid-twentieth century it began to be recognised that as "everyone has the right to education" (UN, 1948, Article 26). Special education was first informed and dominated by the medical model of disability, which finds faults within the individuals by their deficits and sees them as tragic victims with illness to be cured (Allan, 1999; Barton, 1993; Slee, 1998; Tomlinson, 1982). It is essentially a "discourse of deviance" (Skidmore, 2004, p. 113) that constructs the notion of abnormality/ normality, divides the school population into those with SEND and without, and creates the illusion of certain children belonging to certain places of certain expertise.

The three movements that helped to give rise to special education - social Darwinism (eugenics), psychometrics (the measuring of Intelligence Quotient), and scientism (positivism) (Thomas 2014) - are clearly aligned with the medical model that see individuals with disabilities are the problems. Eugenics (Galton, 1869), which, obsessed with the elimination of the 'defectives', maintained a discourse that children with disabilities cannot excel and do not deserve to thrive in mainstream schools or society. Intelligent quotient measuring created a 'sub-class of the intellectually disabled', a concept in part culturally and politically constructed to reinforce the identity and legitimacy of the elite in-group and the exclusion of the disabled out-group (Goodey, 2017). Positivism values objective and quantitatively measured knowledge over subjective and qualitative knowledge. It ignores the 
parents' and children's own perspectives in education and instead assumes that experts must know better what is good for them. This often involves seeing children with SEND as needing certain expertise outside mainstream schools' capacity and therefore necessitating segregated provisions.

In contrast, inclusive education is based on the social and rights-based models that see 'disability' as a socially constructed concept where the disabling society is the problem. Stimulated by the civil rights movement in the United States in the 1950s and 1960s, segregated education for children with disabilities began to be questioned, and themes of 'integration' or 'mainstreaming' increasingly entered education policies. Since the 1980s, the medical model has been challenged by the social model of disability, which, developed by people with disabilities, argues for disability as a socially constructed concept based on contingent social beliefs (Allan 1999; Oliver 1996; Shakespeare \& Watson 1997; Slee 1998). The social model counters the deficit and tragedy discourse within the medical model and challenges the preconception that disability is "abnormal and something to be avoided at all costs" (Oliver \& Barnes 1996, p. 66). Instead, the social model sees the main disablers not within personal impairments, but rather as the prejudice, discrimination, and exclusion in the social contexts. It aims for social and political change where people with disabilities are equally valued as participating citizens and their rights and dignity respected (Alderson \& Goodey, 2018; Finkelstein, 2004).

Thus, within the social model, inclusion is concerned with children's rights to education and school effectiveness, and urges institutional changes that mainstream schools need to improve their capacities and quality of services to meet diverse learner needs. This has recently been reaffirmed as a global commitment in the fourth Sustainable Development Goals initiated by the UN (2015), which explicitly emphasises on ensuring "inclusive and equitable quality education and promote lifelong learning opportunities for all" (ibid., 14). 
This vision has also been reaffirmed in the Incheon Declaration at the World Education Forum (UNESCO, 2015), which maintains a humanistic stance on education and development that is "based on human rights and dignity; social justice; inclusion; protection; cultural, linguistic and ethnic diversity; and shared responsibility and accountability" (ibid., p. 6).

However, doubts of inclusion exist despite the consensus of it being a human right. Main objections come from its practicality in meeting diverse learner needs. For example, Lindsay (1997) notes that apart from the right to be included in mainstream schools, children also have the right to receive an appropriate education that is most suited to their needs. In the shadow of the rights discourse, the language of needs may be neglected (Thomas $\&$ Loxley, 2001). In this regard, Kauffman (1992, p. v) questions:

"under what condition, if any, is an approach to education 'right' even if it doesn't work? Can education or treatment be morally 'right' if it provides no benefit, even if it does harm? Are we to assume that what is 'right' for most students is 'right' for all, regardless of benefit or harm in the individual case?"

Such doubts have been apparent in the UK: Warnock, who first advocated a more inclusive school system (DES, 1978), changed her mind after 30 years and called for a review of the inclusion policy (Warnock \& Norwich, 2010): inclusion is not all children educated under the same roof, and special schools may be the best and only option for some children, as "what is a manifest good in society, and what it is my right to have... may not be what is best for me as a schoolchild" (ibid., p. 36).

Behind these are concerns that mainstream schools may not necessarily have the capacity for inclusion, which at least requires well-trained teachers for the high level of individualisation while maintaining the quality of education for students without disabilities (Costello \& Boyle, 2013; Kauffman, 2015; UNESCO, 2001). Cases of empirical evidence of 
the positive practical benefits of special schools are often highlighted to support such positions (Cook, Ogden \& Winstone, 2016; Harris, Barlow \& Moli, 2008; Reed, Osborne \& Waddington, 2012). In a sense, special schools have been portrayed as fulfilling a child's right to a suitable and beneficial education regardless where the location is. For example, Lindsay and colleagues (2016) conclude in their large-scale study interviewing parents of children with language impairment or on the autistic spectrum in England that it is the quality of provision that matters, not the location per se. Similarly, research have found that a broader notion of inclusion interpreted by special school staff and pupils sees special schools also as 'inclusive' environments where pupils have the sense of belonging, achievements, progress, and enjoyment in learning (Allan \& Brown, 2001; Qu, 2015).

Nevertheless, the evidence supporting special schools are by no means conclusive. There is also a substantial body of research that finds inclusive schools benefit both children with SEND and their typically-developing peers educationally and socially (Demeris, Childs \& Jordan, 2007; Dessemontet \& Bless, 2013; Farrell et al., 2007; Gandhi, 2007; McLeskey, Waldron \& Redd, 2014; Salend \& Garrick-Duhaney, 1999). In short, the debates that are for or against inclusion usually take the two polarised paradigms (the medical or social models), which need to be openly addressed if disagreements are to be resolved.

The social model's contention that society rather than individuals has to change presents disability in a "straightforward, uncomplicated manner in order to convince a very sceptical world" (French, 1993, 24). But the inclusion of children with SEND as part of the call for social change needs a more sophisticated and practically relevant theory of disability than simply rejecting exclusion and the medical model as mistaken. In this regard, for example, Swain and French (2008) proposed an "affirmation model", which aligns with the social model in rejecting the negative stereotyping of people with disabilities but also considers the medical model in affirming their experience of disabilities and individual 
impairments and offering treatments when they are effective. Similarly, scholars (Allan, 2008; Corbett, 1993; Hughes, 2009; Shakespeare, 2006; Shildrick, 2002) have argued against the pure social construction of disability and instead acknowledged disablement within individuals' physical bodies. Both attempts at more sophisticated social models share the common need to see disability in both physical and social terms. The global discourse also increasingly regards disability and inclusive education through a more holistic lens encompassing personal, cultural, political, and socio-economic concerns (UNESCO, 2009, 2015; UNICEF, 2007; WHO, 2011; World Bank, 2013).

However, these multiple perspectives are seldom framed as theoretical constructions. In this regard, Paterson and Hughes $(2000,42)$ write that being unable to construct an adequate theory of disability is "one of the more spectacular failures of modern sociological research”. Such failures may fundamentally stem from the enduring paradigm division and irreconcilable tension between positivism that informs the medical model and interpretivism that underpins the social model.

Following this, the next section illustrates the CR approach to constructing a model of disability that goes beyond the medical/social division and sees these models as constituting different levels of the same reality of 'disability'. This further informs a CR model of inclusive education that highlights the necessity for different fields of professionals to work inclusively together towards different depths of children's best interests.

\section{From Two to Three Dimensions: The CR Model}

Bhaskar and Danermark (2006, p. 280) argued for a "necessarily laminated system" of disability. They critiqued that each of the three main models of disability - medical, socioeconomic, and socio-cultural - "accentuates just one of what are in fact a multiplicity of mechanisms involved in the formation and reproduction of disabilities" (ibid., p. 281). This 
laminated system involves “(i) physical, (ii) biological, and more specifically physiological, medical or clinical, (iii) psychological, (iv) psycho-social, (v) socio-economic, (vi) cultural and (vii) normative kinds of mechanisms, types of context and characteristic effects" (ibid., 288-289). These levels form structured knowledge of disability. The medical model, concerning physical and biological knowledge, and the social models, concerning socioeconomic and cultural knowledge, are clearly different epistemological strata of the same reality of disability. Following this is a CR model of disability that incorporates both the medical and the social models. See Table 2 below.

Table 2. Critical Realist Model of Disability

\begin{tabular}{|c|c|c|c|}
\hline & $\begin{array}{c}\text { Stratified Epistemology of } \\
\text { Disability (Bhaskar \& } \\
\text { Danermark, 2006) }\end{array}$ & $\begin{array}{c}\text { Disability } \\
\text { Models }\end{array}$ & Practices \\
\hline \multirow{3}{*}{$\begin{array}{l}\text { The CR } \\
\text { Model of } \\
\text { Disability }\end{array}$} & $\begin{array}{l}\text { Physical, biological, } \\
\text { physiological, medical, clinical }\end{array}$ & $\begin{array}{c}\text { Medical } \\
\text { Model }\end{array}$ & $\begin{array}{l}\text { Medical care (e.g., medication for } \\
\text { mental health) }\end{array}$ \\
\hline & Psychological, psycho-social & Medical/Social & $\begin{array}{l}\text { Social care (e.g., psychiatrist } \\
\text { counselling, support from social } \\
\text { workers) }\end{array}$ \\
\hline & $\begin{array}{l}\text { Socio-economic, cultural, } \\
\text { political, normative kinds of } \\
\text { mechanisms, types of context } \\
\text { and characteristic effects }\end{array}$ & Social Model & $\begin{array}{l}\text { Enabling social structures (e.g., } \\
\text { accepting and non-stigmatising } \\
\text { views towards mental health, a } \\
\text { supportive social welfare } \\
\text { system). }\end{array}$ \\
\hline
\end{tabular}

This model makes it clear that disability - experiencing hindered participation in society - is emergent from properties within the human bodies but irreducible to them (Alderson, 2013; Bhaskar, 2008). The social cannot be explained or predicted by the natural. To think the medical model alone can sufficiently explain disability is reductionist. On the 
other hand, the social depends on the natural for its existence. If human biology fundamentally changed, society would be organised differently. The social model thus cannot ignore the physical bodies or brains, or replace the medical model by pretending disability is entirely a social construction. The epistemic fallacy (Bhaskar, 2008) is committed when the social understanding of disability and negative labelling of observed differences are mistaken as the whole reality and used to inform policies and practices. Thus, CR brings together the medical and the social and offers a more epistemologically sound understanding of disability.

In education, the CR model of disability helps to make sense of the preference for inclusive over segregated schools. Segregated schools reduce the psychological, social, and cultural needs of the child to physical/medical problems to be fixed. In contrast, inclusive schools recognise the emergent power of the 'disabled bodies' by focusing on enabling participation and meeting a wide range of needs, seeing each child as a whole person. To further understand how inclusive schools need to consider both the medical and the social, the CR stratified ontology offers insights.

At the Empirical, disability may be observed and recognised as biological and/or behavioural differences behind the impairments that individuals may perceive, experience, and at times imagine. Subsequently, medical and technical interventions can be developed at the Actual, intended to reduce such noticeable, perhaps undesirable differences, albeit not always successfully or beneficially. This means medical professionals do have a valuable role to play in inclusive education. For example, cochlear implant enables children with severe to profound hearing loss to hear; and smart prostheses using artificial intelligence technology increase the scope of mobility for children with physical impairments. To wholly reject the medical model is to negate the contribution of modern medicinal development, which is driven by the desire to alleviate pain and enhance, extend and save lives at the Real. Thus, the medical model of disability is relevant and, in many cases, necessary for inclusion. 
However, needs are not just objectively physical but also "relative, historically, socially and politically" (Tomlinson, 1982, p. 75). Inclusion shifts away from the personblaming perspective at the Empirical. It demands that the traditional society, often disabling and oppressive to people with disability, must change. In education, this means that at the Actual, there are needs for broad and relevant curricula, inclusive pedagogies, and conducive learning space. These at the Real are driven by ideals to improve lives, such as rights, equality, respect, dignity, community, compassion, and love, which have been frequently discussed and continuously promoted by major international organisations (UN, 1948, 1989, 2006, 2015; UNESCO, 1994, 2009, 2015, 2017; WHO, 2002, 2011; UNICEF, 2007). See

Table 3 below for this three-dimensional model of inclusive education.

Table 3. Critical Realist Model of Inclusive Education

\begin{tabular}{|c|c|c|}
\hline & \multicolumn{2}{|c|}{ Inclusive Education } \\
\hline & Medical Model & Social Model \\
\hline Empirical & $\begin{array}{l}\text { Observed differences, recognised } \\
\text { physical, biological, physiological, } \\
\text { medical, clinical, psychological } \\
\text { needs and their deeper understanding } \\
\text { in the physical world }\end{array}$ & $\begin{array}{l}\text { Observed differences not stigmatised } \\
\text { as personal faults, diversity valued as } \\
\text { part of wide 'normal' spectrum }\end{array}$ \\
\hline Actual & $\begin{array}{l}\text { High-quality healthcare, } \\
\text { medical/technological advancement } \\
\text { in maximising the physical wellbeing } \\
\text { of human bodies and brains }\end{array}$ & $\begin{array}{l}\text { Curriculum, pedagogy, and assessment } \\
\text { that value a wide range of skills and } \\
\text { knowledge, school activities oriented } \\
\text { towards better meeting diverse learner } \\
\text { needs such as small class sizes, high } \\
\text { teacher-student ratio, encouraging } \\
\text { meaningful participation in learning, } \\
\text { and using Individual Learning Plans or } \\
\text { differentiated education }\end{array}$ \\
\hline Real & $\begin{array}{l}\text { Right to health, to respect for the } \\
\text { worth and dignity of every person, }\end{array}$ & $\begin{array}{l}\text { Right to education and place in } \\
\text { mainstream society, ideals of }\end{array}$ \\
\hline
\end{tabular}




\begin{tabular}{|l|l|l|}
\hline & $\begin{array}{l}\text { ideals of improving lives with less } \\
\text { suffering in the physical world }\end{array}$ & $\begin{array}{l}\text { improving lives with less suffering in } \\
\text { the social world }\end{array}$ \\
\cline { 2 - 3 } & $\begin{array}{l}\text { Respect, dignity, community, wellbeing, participation, love, compassion, } \\
\text { equality, justice, and rights are driving values and motives. }\end{array}$ \\
\hline
\end{tabular}

Therefore, disability and inclusion are better understood when the most useful findings and efforts from the medical and social research and practices can be combined into the larger CR framework of stratified ontology. Advancing medical knowledge on human bodies and brains has helped to demystify the social perception of disability beyond believing it to be a 'curse' or 'madness'. The social understanding of bodies as self-determining, meaning-making agents in turn urges medical practices to become more ethical and socially aware. In schools, under the medical model, Picture Exchange Communication System (Boesch et al., 2013; Bondy \& Frost, 1994; Cagliani et al., 2017) and Applied Behaviour Analysis (Baer, Wolf \& Risley, 1968; Kearney, 2015), for example, are found to have some beneficial outcomes in facilitating social interactions. Under the social model, Inclusive Pedagogy (Florian \& Black-Hawkins, 2011; Hart et al., 2004; Spratt \& Florian, 2015) and frameworks for developing inclusive education (Booth \& Ainscow, 2011; Dyson et al., 2010; Hargreaves, 2009) have also advanced school and classroom practices.

This paper thus suggests the CR model as a new framework for the global inclusion debate. As Tomlinson (1982, p. 27) reminds:

\footnotetext{
"education systems and their parts do not develop spontaneously, or in an evolutionary manner, and they do not develop out of purely humanitarian motives. They develop because it is in the interests of particular groups in a society that they should develop and that they should develop in particular ways ... what actually becomes 'education' is seldom the realisation of some ideal form of instruction."
} 
This means that education for children with SEND is not only about the Empirical where 'ideal' technical interventions can be realised, as it often claims. Rather, it is also about the Actual, where powerful groups protect and fulfil their vested interests (e.g., governments and employers demanding a productive labour force, schools scoring high ranking on the league tables). Deeply, this arises from the Real: the focus on neo-liberalism and utilitarianism in today's educational and social values. Thus, for inclusion to work, a different version of the Real is needed: one where educational development embodies more humanitarian motives; this correspondingly informs the Actual, where institutional changes are needed to break down structural barriers; together with effective technical interventions at the Empirical, schools can strive to become more inclusive to meet all learner needs.

Thus, simply trying to reject the medical and replace it with the social model has been largely ineffective, as such attempt itself is ontologically invalid in CR terms. Rather than rejecting the medical model, parts of the model needs to be acknowledged as 'real' at the Empirical; the social model at the Actual counters the negative stereotyping of the medical focus by highlighting the existence of a deeper reality of disability but it does not exclude the 'disabled bodies' at the Empirical; essentially, the Real - values and drives such as rights, equality, and justice - needs to be closely seen as having the causal powers in the material world rather than simply utopian ideals only 'real' in the form of ideas. Following this, in special and inclusive education, the CR model offers a theoretical basis for educators and specialists to make sense of their roles. Neither side can claim to have the only best interest of the child at heart. Rather, they are both needed to work together towards different depths of children's best interests - their right to health and to education -, with the common goal of creating an inclusive model of society within schools based on equality, justice, and rights. 


\section{Conclusion}

The ways 'disability' is viewed can inform the design of education for children with SEND. Having reviewed the 'paradigm war' between 'positivism - medical model - segregated schools' and 'interpretivism - social model - inclusive schools', this paper contends that a CR model of inclusive education may be able to move the inclusion debates forward, as the CR stratified ontology offers the necessary theoretical groundings to bridge such divides and to make sense of the inner connections among the key disagreements that have so far contributed to the conceptualisation of disability from different perspectives.

The usefulness of a CR model of inclusive education is to paint a holistic picture beyond the usually isolated single focal points in education. Different fields of professionals need to work inclusively together towards different depths of children's best interests, such as physical, psychological, academic, social, and cultural. As Armstrong (2002, p. 56) suggests, all sectors in society and participants from all disciplines need to be involved as part of a global inclusion debates and efforts, as opposed to just narrowly focusing on vulnerable minority groups, or otherwise inclusion would be "no more than an intellectual exercise". This necessity has been illustrated in this paper at the Empirical, the Actual, and the Real of inclusive education. I hope this paper will invite more interest in critical realism in future research in inclusive education. Uncovering the real causes helps to guide real social change.

\section{References}

Alderson, P. (2013) Childhoods real and imagined: An introduction to critical realism and childhood studies, vol.1. (Abingdon: Routledge).

Alderson, P. \& Goodey, C. (2018) Enabling education: Experiences in special and ordinary schools. (London, Tufnell Press).

Allan, J. (1999) Actively seeking inclusion: Pupils with special needs in mainstream schools: Insiders, outsiders and deciders. (London: Routledge).

Allan, J. (2010) The sociology of disability and the struggle for inclusive education. British Journal of Sociology of Education, 5(31), 603-619. 
Allan, J. \& Brown, S. (2001) Special schools and inclusion. Educational Review, 53 (2), 199207.

Armstrong, F. (2002) Managing difference: Inclusion, performance and power. Critical Quarterly, 44, 51-56.

Armstrong, D. (2018) Wicked problems in special and inclusive education. Journal of Research in Special Educational Needs, 17(4), 229-236.

Baer, D. M., Wolf, M. M. \& Risley, T. R. (1968) Some Current Dimensions of applied behaviour analysis. Journal of Applied Behaviour Analysis, 1 (1), 91-97.

Barton, L. (1993) The struggle for citizenship: The case of disabled people. Disability, Handicap and Society, 8(3), 235-48.

Bhaskar, R. (1998) The possibility of naturalism: A philosophical critique of the contemporary human sciences ( $3^{\text {rd }} E d$.). (New York: Routledge).

Bhaskar, R. (2008) A realist theory of science. (London and New York: Routledge).

Bhaskar, R. (2009) Scientific realism and human emancipation $\left(2^{\text {nd }}\right.$ Ed). (Abingdon: Routledge).

Bhaskar, R., Naess, P., Parker, J., Frank, C. and Hoyer, K. G. (Eds). (2010) Interdisciplinarity and climate change: Transforming knowledge and practice for our global future. (London: Routledge).

Bhaskar, R. \& Danermark, B. (2006) Metatheory, interdisciplinarity and disability research: A critical realist perspective. Scandinavian Journal of Disability Research, 8 (4), 27897.

Boesch, M., Wendt, O., Subramanian, A. \& Hsu, N. (2013) Comparative efficacy of the Picture Exchange Communication System (PECS) versus a speech-generating device: Effects on requesting. Research in Autism Spectrum Disorders, 7, 480-493.

Booth, T. \& Ainscow, M. (2011) The index for inclusion: Developing learning and participation in schools. (London: CSIE).

Bondy, A. \& Frost, L. (1994) The picture exchange communication system. Focus on Autistic Behaviour, 9, 1-19.

Cagliani, R., Ayres, K., Whiteside, E. \& Ringdahl, J. (2017) Picture Exchange Communication System and delay to reinforcement. Journal of Developmental and Physical Disabilities, 29, 925-939.

Collier, A. (1999) Being and worth. (NY: Routledge).

Cook, A., Ogden, J. \& Winstone, N. (2016) The experiences of learning, friendship and bullying of boys with autism in mainstream and special settings: A qualitative study. British Journal of Special Education, 43, 250-271.

Corbett, J. (1993) Postmodernism and the "special needs" metaphors. Oxford Review of Education. 19, 547-53.

Costello, S. \& Boyle, C. (2013) Pre-service secondary teachers' attitudes towards inclusive education. Australian Journal of Teacher Education, 38, 129-143.

Danermark, B., Ekstrom, M. \& Jakobsen, L. (2001) Explaining society: An introduction to critical realism in the social sciences. (New York and London: Routledge).

Demeris, H., Childs, R. A. \& Jordan, A. (2007). The influence of students with special needs included in grade- 3 classrooms on the large-scale achievement scores of students without special needs. Canadian Journal of Education, 30, 609-627.

DES [Department of Education and Science] (1978) Special educational needs: Report of the Committee of Enquiry into the education of handicapped children and young people (The Warnock Report). (London: DES).

Dessemontet, R. S. \& Bless, G. (2013) The impact of including children with intellectual disability in general education classrooms on the academic achievement of their low-, 
average-, and high-achieving peers. Journal of Intellectual \& Developmental Disability, $38,23-30$.

DfE [Department of Education of the UK] (2017) Special educational needs in England: January 2017. (London: DfE).

Dyson, A., Goldrick, S., Jones, L. \& Kerr, K. (2010) Equity in education: Creating a fairer education system: A manifesto for the reform of education in England. (Manchester: Centre for Equity in Education).

Farrell, P., Dyson, A., Polat, F., Hutcheson, G. \& Gallannaugh, F. (2007) Inclusion and achievement in mainstream schools. European Journal of Special Needs Education, 22, $131-145$.

Finkelstein, V. (2004) Representing disability. In: J. Swain, S. French, C. Barnes and C. Thomas (Eds.), Disabling Barriers - Enabling Environments, 2nd ed. (London: Sage Publications).

Florian, L. \& Black-Hawkins, K. (2011) Exploring inclusive pedagogy. British Educational Research Journal, 37 (5), 813-828.

French, S. (1993) Disability, impairment or something in between. In: J. Swain, S. French, C. Barnes and C. Thomas (Eds.), Disabling barriers, enabling environments. (London: Sage).

Galton, F. (1869) Hereditary genius: An inquiry into its laws and consequences. (London: Macmillan).

Gandhi, A. G. (2007) Context matters: Exploring relations between inclusion and reading achievement of students without disabilities. International Journal of Disability, Development and Education, 54, 91-112.

Goodey, C. (2017) Learning disability and inclusion phobia: Past, present, future. (London: Routledge).

Gorski, P. S. (2013) What is critical realism? And why should you care? Contemporary Sociology: A Journal of Reviews, 42 (5), 658-670.

Guan, W. J. (2017) [In Chinese]. The features of classroom participation by students with disabilities and teachers' support at inclusive schools. Chinese Journal of Special Education, 201, 3-10.

Hammersley, M. (2012) Methodological Paradigms in Educational Research, British Educational Research Association on-line resource. Retrieved from: https://martynhammersley.files.wordpress.com/2013/11/methodological-paradigms4.pdf

Hargreaves, A. (2009) The fourth way: The inspiring future for educational change. (Thousand Oaks, CA: Corwin).

Hart, S., Dixon, A., Drummond, M. J. \& McIntyre, D. (2004) Learning without limits. (Maidenhead: Open University Press).

Harris, A. \& Enfield, S. (2003) Disability, equality and human rights: A training manual for development and humanitarian organisations. (Oxford: Oxfam \& Action Aid on Disability and Development).

Harris, L., Barlow, J. \& Moli, P. (2008) Specialist residential education for children with severe emotional and behavioural difficulties: pupil, parent, and staff perspectives. Emotional and Behavioural Difficulties, 13 (1), 31-47.

Head, G., Kane, J. \& Cogan, M. (2002) An evaluation of behaviour support in one Scottish education authority. (Glasgow: Glasgow University Press).

Hughes, B. (2009) Wounded/monstrous/abject: a critique of the disabled body in the sociological imaginary. Disability and Society, 24(4), 399-410. 
Kearney, A. J. (2015) Understanding applied behaviour analysis: An introduction to ABA for parents, teachers, and other professionals. (London and Philadelphia: Jessica Kingsley Publishers).

Kauffman, J. M. (1992) Foreword. In: K. R. Howe and O. B. Miramontes, The ethics of special education. (New York: Teachers College Press).

Kauffman, J. M. (2015). Why we should have special education? In: B. Bateman, J. W. Lloyd and M. Tankersley (Eds.), Enduring issues in special education - Personal perspectives. (London: Routledge).

Lindsay, G. (1997) Values, rights and dilemmas. British Journal of Special Education, 24 (2), $55-9$.

Lindsay, G. (2007) Annual review: educational psychology and the effectiveness of inclusive education/mainstreaming. The British Psychological Society, 77, 1-24.

Lindsay, G., Ricketts, J., Peacey, L. V., Dockrell, J. E. \& Charman, T. (2016) Meeting the educational and social needs of children with language impairment or autism spectrum disorder: The parents' perspectives. International Journal of Language \& Communication Disorders, 51, 495-507.

Loreman, T. (2014) Measuring inclusive education outcomes in Alberta, Canada. International Journal of Inclusive Education, 18 (5), 459-483.

McLeskey, J., Waldron, N. L. \& Redd, L. (2014) A case study of a highly effective, inclusive elementary school. The Journal of Special Education, 48, 59-70.

NBS [National Bureau of Statistics of China] (2000) [In Chinese]. China statistical yearbook of 1999. (Beijing: NBS).

NBS (2017) [In Chinese]. China statistical yearbook of 2016. (Beijing: NBS).

Norwich, B. (2008). Dilemmas of difference, inclusion and disability: international perspectives and future directions. (London: Routledge).

Oliver, M. (1996). Understanding disability: From theory to practice. (Basingstoke: Macmillan).

Oliver, M. \& Barnes, C. (1996). Disabled people and social policy: From exclusion to inclusion. (London: Longman).

Paterson, K. \& Hughes, B. (2000). Disabled bodies. In: P. Hancock, B. Hughes, E. Jagger, K. Patterson, R. Russell, E. Tulle-Winton and M. Tylor (Eds.), The body, culture and society: An introduction. (Buckingham: Open University Press).

Porpora, D. V. (2015). Reconstructing sociology: The critical realist approach. (Cambridge: Cambridge University Press).

Qu, X. (2015) Understanding special school provision for children with severe learning difficulties in relation to inclusive education. Cambridge Open-Review Educational Research e-Journal, 1 (2), 78-98.

Quicke, J., Beasley, K. \& Morrison, C. (1990) Challenging prejudice through education. (London: Falmer).

Reed, P., Osborne, L. \& Waddington, E. (2012) A comparative study of the impact of mainstream and special school placement on the behaviour of children with autism spectrum disorders. British Educational Research Journal, 38 (5), 749-763.

Salend, S. J. \& Garrick-Duhaney, L. M. (1999) The impact of inclusion on students with and without disabilities and their educators. Remedial and Special Education, 20, 114-126.

Sayer, A. (2000) Realism and social science. London: Sage.

Shakespeare, T. (2006) Disability rights and wrongs. London: Routledge.

Shakespeare, T. \& Watson, N. (1997) Defending the social model. Disability and society, 12 (2), 293-300.

Shildrick, M. (2002) Embodying the monster: Encounters with the vulnerable self. (London: Sage). 
Slee, R. (1998) The politics of theorizing special education. In: C. Clark, A. Dyson and A. Millward (Eds.), Theorising special education. (London: Routledge).

Skidmore, D. (2004) Inclusion: The dynamic of school development. (Buckingham/ Philadelphia: Open University Press).

Spratt, J. \& Florian, L. (2015) Inclusive pedagogy: From learning to action. Supporting each individual in the context of 'everybody'. Teaching and Teacher Education, 49, 89-96.

Swain, J. \& French, S. (2008) Disability on equal terms. (London: Sage).

Taber, K. S. (2012) Prioritising paradigms, mixing methods, and characterising the 'qualitative' in educational research. Teacher Development, 16 (1), 125-138.

Thomas, G. (2014) Epistemology and special education. In: L. Florian (Ed.), The SAGE handbook of special education. (London: Sage).

Thomas, G. \& Loxley, A. (2001) Deconstructing special education and constructing inclusion. (Buckingham/Philadelphia: Open University Press).

Tomlinson, S. (1982). A sociology of special education. (London: Routledge).

UN (1948) Universal declaration of human rights. (New York: United Nations).

UN (1989) The United Nations Convention on the rights of the child. (New York: United Nations).

UN (2006) The convention on the rights of persons with disabilities. (New York: UN).

UN (2015) Transforming our world: The 2030 agenda for sustainable development. (New York: UN).

UNESCO [ United Nations Educational, Scientific and Cultural Organisation] (1994) The Salamanca statement and framework for action on special needs education. (Paris: UNESCO).

UNESCO (2001) The open file on inclusive education. (Paris: UNESCO).

UNESCO (2009) Policy guidelines on inclusion in education. (Paris: UNESCO).

UNESCO (2015) The Incheon declaration - Education 2030: Towards inclusive and equitable quality education and lifelong learning for all. (Paris: UNESCO).

UNESCO (2017) A guide for ensuring inclusion and equity in education. (Paris: UNESCO).

UNICEF (2007) A human rights-based approach to education. (New York: UNICEF).

Warnock, M. \& Norwich, B. (2010) Special educational needs: A new look. London and (New York: Continuum).

WHO [World Health Organisations] (2002) Towards a common language for functioning, disability and health. (Geneva, WHO).

WHO (2011) World report on disability. (Geneva, WHO).

World Bank (2013) Inclusion matters - The foundation for shared prosperity. (Washington DC: World Bank). 